\title{
Universiteit
}

Leiden

The Netherlands

\section{Identification and isolation of lantibiotics from culture: a bioorthogonal chemistry approach}

Li, J.; Girard, G.; Florea, B.I.; Geurink, P.P.; Li, N.; Marel, G.A. van der; ... ; Wezel, G.P. van

\section{Citation}

Li, J., Girard, G., Florea, B. I., Geurink, P. P., Li, N., Marel, G. A. van der, ... Wezel, G. P. van. (2012). Identification and isolation of lantibiotics from culture: a bioorthogonal chemistry approach. Organic And Biomolecular Chemistry, 10(43), 8677-8683. doi:10.1039/C2OB26050F

Version: Publisher's Version

License: $\quad$ Licensed under Article 25fa Copyright Act/Law (Amendment Taverne)

Downloaded from: https://hdl.handle.net/1887/3203757

Note: To cite this publication please use the final published version (if applicable). 


\title{
Organic \& \\ Biomolecular \\ Chemistry
}

Cite this: Org. Biomol. Chem., 2012, 10,8677

WwW.rsc.org/obc

PAPER

\section{Identification and isolation of lantibiotics from culture: a bioorthogonal chemistry approach $\uparrow$}

\author{
Jing Li, ${ }^{a}$ Genevieve Girard, ${ }^{b}$ Bogdan I. Florea, ${ }^{a}$ Paul P. Geurink, ${ }^{a}$ Nan Li, ${ }^{a}$ Gijsbert A. van der Marel, ${ }^{a}$ \\ Mark Overhand, ${ }^{a}$ Herman S. Overkleeft ${ }^{* a}$ and Gilles P. van Wezel ${ }^{* b}$
}

Received 31st May 2012, Accepted 10th September 2012

DOI: $10.1039 / \mathrm{c} 2 \mathrm{ob26050f}$

A distinguishing feature of the lantibiotic family of cyclic peptides is the presence of thioethers.

Treatment of a lantibiotic with an alkaline solution at high $\mathrm{pH}$ gives rise to a $\beta$-elimination reaction

yielding the corresponding ring opened precursor, containing a dehydro-amino acid residue. We here reveal in a proof-of-concept study that a ring opened lantibiotic (mersacidin) can be captured for pulldown from a culture broth, subsequently released and identified by mass spectrometry.

\section{Introduction}

Due to the rapid spread of drug-resistant infectious diseases a point of no return has been reached where novel antibiotics are an absolute necessity. ${ }^{1}$ However, it has become increasingly difficult to find novel classes of antibiotics with efficacy against multi-drug resistant pathogens such as MDR-TB (multi-drug resistant Mycobacterium tuberculosis), MRSA (methicillinresistant Staphylococcus aureus) and the rapidly emerging MDR Gram-negative pathogens. Actinomycetes are prolific antibiotic producers, and full genome sequencing efforts have established that even the widely studied species are still relatively untapped sources of natural products. Around 20 new gene clusters encoding natural products were found on the genome of the actinomycete Streptomyces coelicolor alone. ${ }^{2}$ This suggests the presence of silent antibiotics, and new approaches are required to identify these. ${ }^{3}$ One promising class of antibiotics is that of the lantibiotics, peptide antibiotics that are characterized by the presence of one or more cyclic thioether linkages. ${ }^{4}$ Nisin, the first discovered lantibiotic and produced by the firmicute Lactococcus lactis, is used as a food preservative and no significant bacterial resistance has thus far been encountered. ${ }^{5}$ At present, more than 50 different lantibiotics produced by Gram-positive bacteria are known with diverse structure and function, and due to the nextgeneration sequencing technology many new lantibiotic gene clusters are being discovered. Lantibiotics show substantial specificity for bacterial cell membrane components, including lipid II and phosphoethanolamine, and act on pathogenic

${ }^{a}$ Leiden Institute of Chemistry and Netherlands Proteomics Centre,

Gorlaeus Laboratories, Einsteinweg 55, 2333 CC Leiden,

The Netherlands. E-mail: h.s.overkleeft@chem.leidenuniv.nl

${ }^{b}$ Institute Biology Leiden, Sylviusweg 72, 2300 RA Leiden,

The Netherlands

$\dagger$ Electronic supplementary information (ESI) available. See DOI: $10.1039 / \mathrm{c} 2 \mathrm{ob} 26050 \mathrm{f}$ bacteria by pore formation or inhibition of peptidoglycan biosynthesis. ${ }^{6}$ Some lantibiotics combine more than one mode of action, allowing them to escape resistance mechanisms. ${ }^{7}$ These properties classify the lantibiotics as an interesting class of molecules and a viable target for the discovery and development of novel antimicrobial therapeutics. ${ }^{8}$

Lantibiotics are ribosomally synthesized as linear pro-peptides and post-translationally modified to their biologically active thioether containing forms. Following secretion, the leader peptide is removed, creating the mature lantibiotic (typically around $2 \mathrm{kDa}$ ). Studies of the biosynthesis of lantibiotics suggest that the post-translational modifications generally involve a two-step procedure in which threonine and serine residues of the precursor oligopeptides are enzymatically dehydrated to form dehydrobutyrine and dehydroalanine residues, respectively. ${ }^{9}$ These unsaturated amino acid residues serve as electrophiles on which the thiolates of cysteine residues can attack via intra-molecular 1,4-addition followed by stereoselective protonation of the resulting enolate to create a $\beta$-methyllanthionine or lanthionine moiety, respectively. Lantibiotics containing several thioether rings may result from programmed post-translational modification steps. Recently, it was found that even more complex ring structures can be obtained when the resulting enolate is not protonated but serves as a nucleophile in an additional intramolecular 1,4-addition reaction. ${ }^{10}$ The thioether rings of certain lantibiotics can be chemically reversibly opened following an elimination reaction at high $\mathrm{pH}$ and elevated temperature (Scheme 1). The resulting ring opened intermediates can be trapped by the addition of an excess of a thiol reagent, such as mercaptoethanol. Several ring opened derivatives can thus be prepared and this strategy has been successfully applied for the sequence analysis of the lantibiotics galidermin, Pep5 and actagardine using NMR spectroscopy. ${ }^{11}$ It occurred to us that this chemical feature of lantibiotics may be generally applied in a two-step labeling strategy ${ }^{12}$ for the discovery of novel 


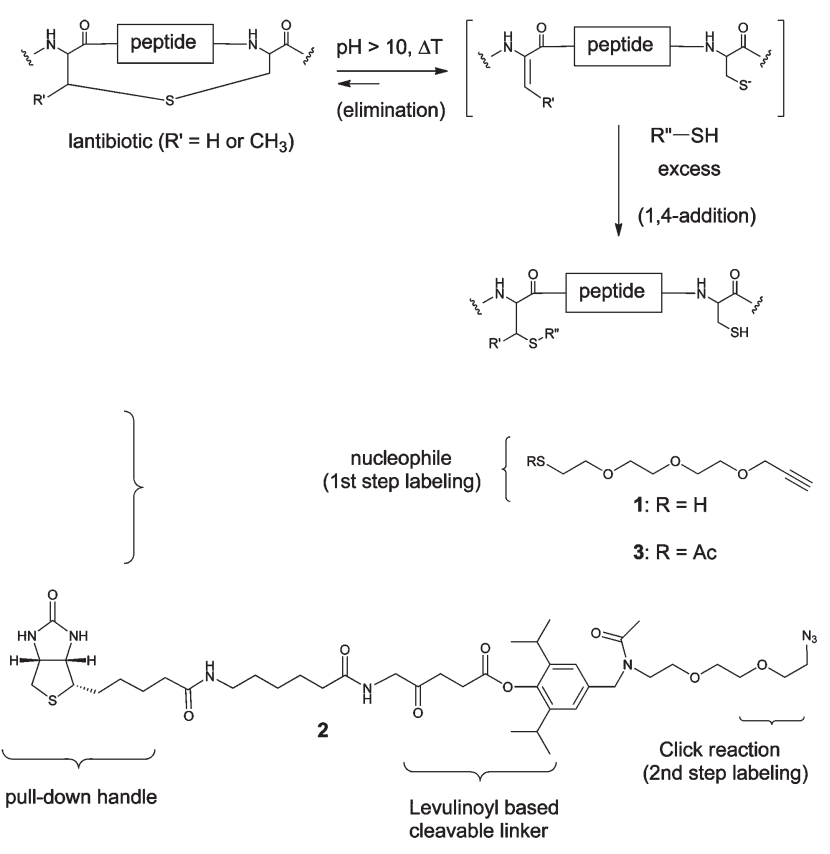

Scheme 1 The opening of a thioether linkage of a lantibiotic antimicrobial peptide and the trapping of the ring opened intermediate using excess thiol reagent, and the structures of the designed probes $\mathbf{2}$ and $\mathbf{1}$ (generated in situ from 3) used in the two-step labeling strategy.

lantibiotics produced by bacillus and streptomyces bacterial strains. For this purpose we designed the probes $\mathbf{2}$ and $\mathbf{3}$ (Scheme 1). The free thiol 1, generated in situ from $\mathbf{3}$ under the strong basic reaction conditions of the elimination reaction, is equipped with an acetylene moiety for a projected click reaction $^{13}$ with the azide moiety of probe 2 . Probe 2 contains a biotin handle for recognition using streptavidin beads and a hydrazine sensitive cleavable linker we previously described for chemical proteomics purposes. ${ }^{14}$ We here reveal that probes 2 and $\mathbf{3}$ can be used in a two-step labeling protocol to identify the known lantibiotic mersacidin ${ }^{15}$ from Bacillus subtilis fermentation broth.

\section{Results and discussion}

The synthesis of compounds $\mathbf{2}$ and $\mathbf{3}$ is described in Scheme 2. Triethylene glycol was alkylated using sodium hydride and propargyl bromide, subsequently converted into its tosylate and treated with potassium thioacetate to obtain compound 3 in $25 \%$ yield over 3 -steps. Compound $\mathbf{4}^{17}$ was treated with 5 -azido-4oxopentanoate in the presence of $10 \% \mathrm{Pd} / \mathrm{C}$ to give $\mathbf{5}$ in $73 \%$ yield. Ester $\mathbf{5}$ was readily saponified to provide compound $\mathbf{6}$ in $87 \%$ yield. Carboxylic acid 6 was reacted with the phenol 7, obtained in a three step one pot procedure from 1,2-bis(2-azidoethoxy)ethane, in the presence of EDC/DMAP to give product 2 in only $15 \%$ yield. The low yield of the former reaction is likely due to severe steric hindrance of the aromatic hydroxyl.

Once synthesized, we proceeded to evaluate their reactivity using the known lantibiotic mersacidin $\left(\mathrm{C}_{80} \mathrm{H}_{120} \mathrm{~N}_{20} \mathrm{O}_{21} \mathrm{~S}_{4}, \mathrm{MW}\right.$ 1824.78 Da), containing three methyllanthionine residues, one dehydroalanine residue and one $S$-aminovinyl-2-methylcysteine moiety. ${ }^{16}$ We first investigated the efficiency of our probes using

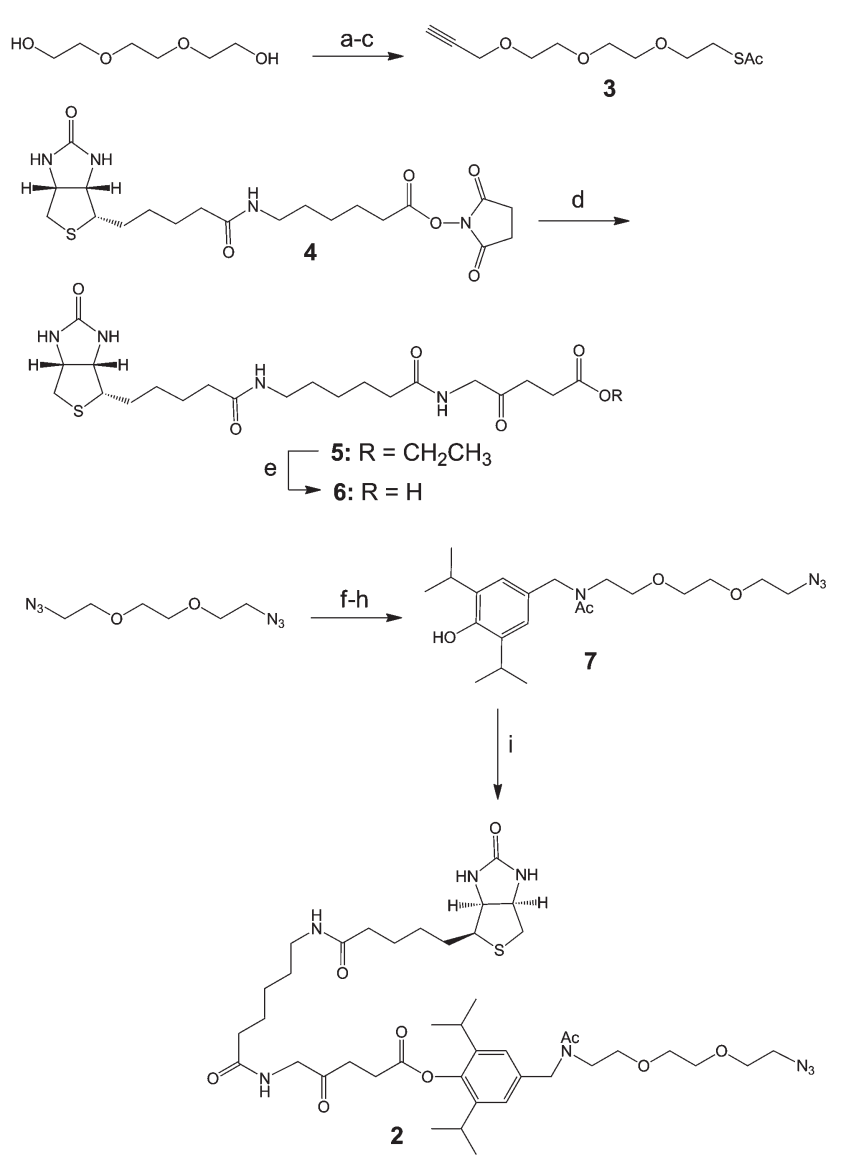

Scheme 2 (a) $\mathrm{NaH}$, propargyl bromide in THF. (b) $\mathrm{TsCl}_{2} \mathrm{NEt}_{3}$ in $\mathrm{CH}_{2} \mathrm{Cl}_{2}$. (c) $\mathrm{KSAc}$ in DMF. (d) Ethyl 5-azido-4-oxopentanoate, $\mathrm{Pd} / \mathrm{C}$, $\mathrm{H}_{2}$ in methanol. (e) $2 \mathrm{M} \mathrm{NaOH}$ in methanol. (f) $\mathrm{PPh}_{3}, \mathrm{THF} / \mathrm{H}_{2} \mathrm{O} 4 / 1$ v/v. (g) 4-Hydroxy-3,5-diisopropylbenzaldehyde, $\mathrm{NaOH}, \mathrm{NaBH}_{4}$ in methanol. (h) $\mathrm{Ac}_{2} \mathrm{O}$. (i) Compound 6, EDC, DMAP in DMF.

pure mersacidin (Scheme 3) and used the optimized conditions to identify this lantibiotic from B. subtilis (Scheme 4). Complete conversion of mersacidin was accomplished in aqueous methanol at $\mathrm{pH}>10$ at $50{ }^{\circ} \mathrm{C}$ for $1 \mathrm{~h}$ using 30 equiv. of compound $\mathbf{3}$ (Scheme 2, step A). LC/MS analysis showed that mersacidin was completely converted into its anticipated products with the addition of one, two and three sulfide-alkyne moieties (HSA) (Fig. S1, ESI $\dagger$ ). This is indicated by the ions $m / z$ 1037.00 Da $\left[\mathrm{M}+\mathrm{HSA}+\mathrm{Ac}+2 \mathrm{H}^{+}\right]^{2+}, 1139.00 \mathrm{Da}[\mathrm{M}+2 \mathrm{HSA}+\mathrm{Ac}+$ $\left.2 \mathrm{H}^{+}\right]^{2+}$ and $1240.67 \mathrm{Da}\left[\mathrm{M}+3 \mathrm{HSA}+\mathrm{Ac}+2 \mathrm{H}^{+}\right]^{2+}$. By performing MS/MS sequencing it was found that the single mersacidin modified product is labeled at position 13 in the sequence (Fig. S2, ESI†). The additional acetyl group in the products at the N-terminus is probably obtained by a reaction involving the deacetylation of 3. In addition, the in situ generated reactive intermediate 1 was found to dimerize during the reaction. To prevent labeling via $\mathrm{S}-\mathrm{S}$ bond formation, a reduction step (using DTT) and an alkylation step (using iodoacetamide) were introduced (Scheme 3 step B, LC/MS analysis is shown in Fig. S3, ESI $\dagger$ ). Copper(I)-catalyzed azide-alkyne cycloaddition between the alkyne modified mersacidin and biotin-azide 2 (Scheme 3, step C) was complete within $17 \mathrm{~h}$ at room temperature according to LC/MS analysis (Fig. S4, ESI $\dagger$ ). The corresponding labeled 

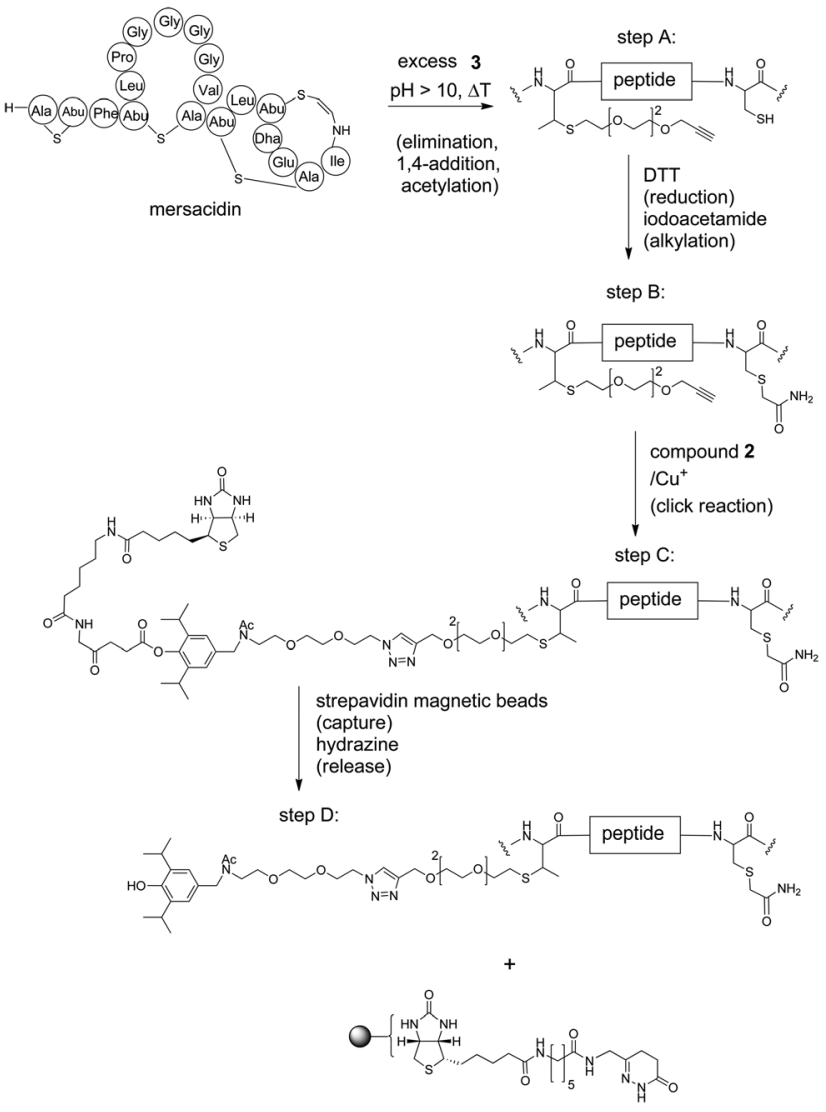

Scheme 3 Protocol for the two-step labeling of the lantibiotic mersacidin.

products are indicated by ions $m / z 1466.53 \mathrm{Da}$ [M $+\mathrm{HSA}+\mathrm{Ac}$ + Biotin $\left.+2 \mathrm{H}^{+}\right]^{2+}$ and 1494.60 Da $[\mathrm{M}+\mathrm{HSA}+\mathrm{Ac}+\mathrm{AA}+$ Biotin $\left.+2 \mathrm{H}^{+}\right]^{2+}$. With these products in hand the optimal conditions for the cleavage of the levulinolate-linkage were examined (Fig. S5, ESI †े) and subsequently applied by pull down of the labeled products using streptavidin coated magnetic beads followed by treatment of the beads with $0.1 \mathrm{M}$ hydrazine at $37^{\circ} \mathrm{C}$ for $4 \mathrm{~h}$ (Scheme 3, step D). The resulting solution was characterized with LC/MS. The corresponding products were found as a major $(m / z 1240.00 \mathrm{Da}$ [M + HSA + Ac + Biotin-C + $\left.\left.2 \mathrm{H}^{+}\right]^{2+}\right)$ and a minor signal $(\mathrm{m} / z$ 1268.47 $\mathrm{Da}[\mathrm{M}+\mathrm{HSA}+\mathrm{Ac}+$ IAA + biotin-C $\left.+2 \mathrm{H}^{+}\right]^{2+}$, Fig. S6, ESI, $\dagger$ HRMS, Fig. S7†).

In the key experiment, Bacillus sp. H1L Y 8554728 was incubated, the supernatant collected and the crude products applied on a size-exclusion chromatography column. As indicated by LC/MS mersacidin is present in the fermented sample along with numerous other components, and the size-exclusion chromatography step thus mainly serves to concentrate the fermentation sample (Scheme 4). The obtained sample was treated with the above described protocol steps A-D involving reaction with in situ generated probe $\mathbf{1}$ at high $\mathrm{pH}$ and elevated temperature, followed by $\mathrm{S}-\mathrm{S}$ bond reduction, alkylation, dialysis, click reaction using probe 2 , pull down with streptavidin-coated magnetic beads and hydrazine cleavage. The resulting products were analyzed with LC/MS. Following this protocol mersacidin was isolated from culture and identified by the mass of the resulting derivative with mass $m / z 1239.93 \mathrm{Da}[\mathrm{M}+\mathrm{HSA}+\mathrm{Ac}+$ biotin-
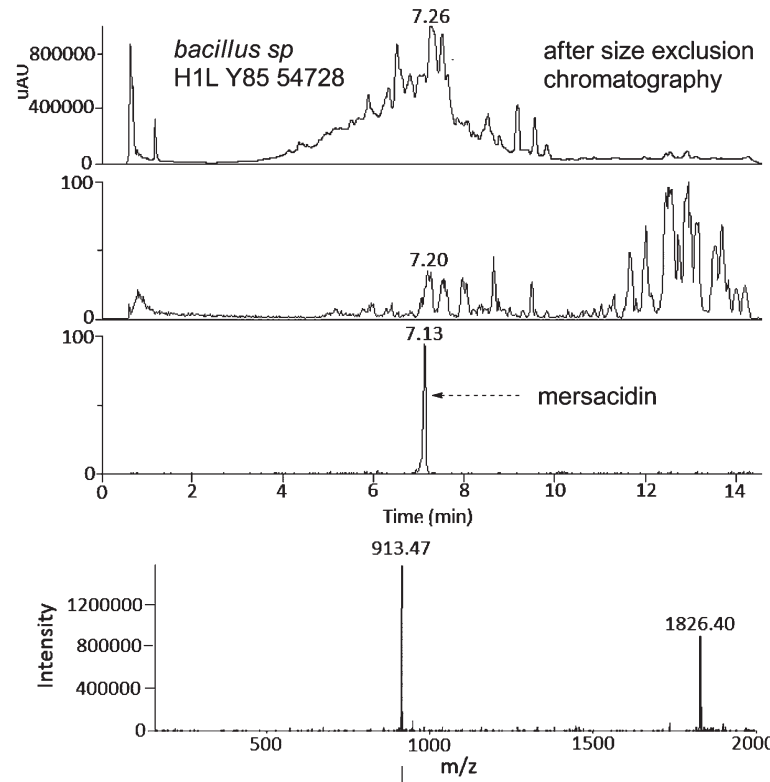

step A-D
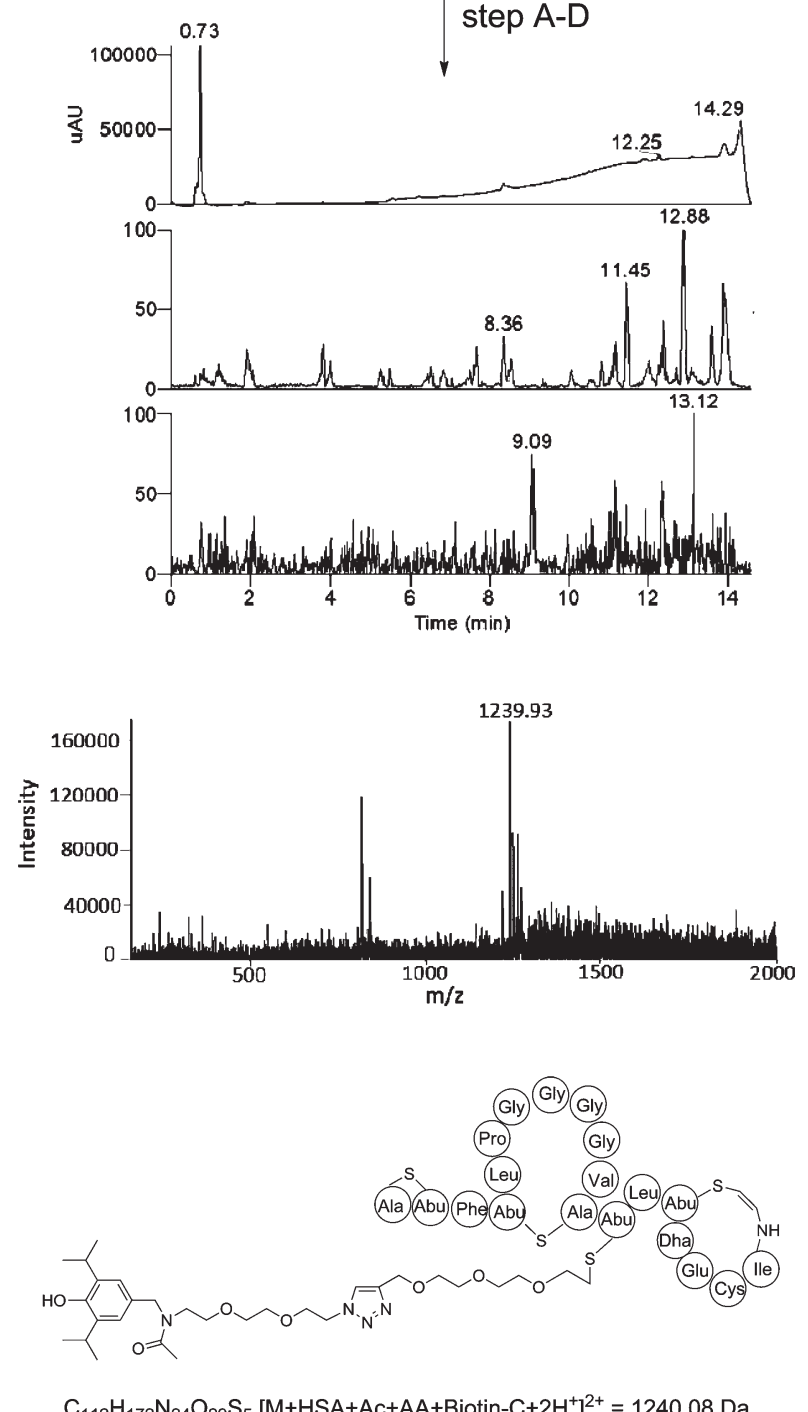

Scheme 4 Two-step labeling strategy for the identification of mersacidin from cultured Bacillus sp. H1L Y85 54728. 
$\left.\mathrm{C}+2 \mathrm{H}^{+}\right]^{2+}$ (Scheme 4, the $S$-acetamide alkylated product could not be clearly detected).

\section{Conclusion}

Two probes were designed and synthesized for a two-step labeling strategy to identify lantibiotic peptides following opening of one (or more) of the characteristic thio-ether linkages. Using this strategy, involving a first step labeling via an elimination/1,4addition reaction, a second step labeling with a click reaction, and pull-down of the modified peptide products using streptavidin beads and hydrazine-induced release, we positively identified the lantibiotic mersacidin in a fermentation sample of Bacillus sp. H1L Y85 54728. The concentration of mersacidin in a fermented sample is typically $1-10 \mathrm{mg} \mathrm{L^{-1 }}$. Our procedure involves the use of a size-exclusion chromatography step to concentrate the sample. We are currently evaluating the heredescribed approach to identify unknown lantibiotics from cultures produced by actinomycetes.

\section{Experiment section}

\section{General methods}

All reagents used were purchased from commercial sources and were used without further purification. Solvents that were used in reactions were stored over $4 \AA$ molecular sieves, except methanol and acetonitrile, which were stored over $3 \AA$ molecular sieves. Molecular sieves were flame dried before use. Tetrahydrofuran was distilled over $\mathrm{LiAlH}_{4}$ prior to use. The eluents ethyl acetate (EtOAc) and petroleum ether $\left(40-60{ }^{\circ} \mathrm{C}\right.$ boiling range) were distilled prior to use. Mersacidin was provided by Novacta (UK). Bacillus was cultured in an Innova 4000 incubator shaker. Column chromatography was performed on Screening Devices b.v. Silica Gel, with a particle size of $40-63 \mu \mathrm{m}$ and a pore diameter of $60 \AA$. Unless stated otherwise, all reactions were monitored by TLC on Merck aluminum sheets (Silica gel 60 F254). Spots were detected under UV light ( $254 \mathrm{~nm})$, and/or by spraying with a solution of $\left(\mathrm{NH}_{4}\right)_{6} \mathrm{Mo}_{7} \mathrm{O}_{24} \cdot 4 \mathrm{H}_{2} \mathrm{O}\left(25 \mathrm{~g} \mathrm{~L}^{-1}\right)$ and $\left(\mathrm{NH}_{4}\right)_{4} \mathrm{Ce}\left(\mathrm{SO}_{4}\right)_{4} \cdot 2 \mathrm{H}_{2} \mathrm{O}\left(10 \mathrm{~g} \mathrm{~L}^{-1}\right)$ in $10 \%$ sulfuric acid, or a solution of $\mathrm{KMnO}_{4}\left(20 \mathrm{~g} \mathrm{~L}^{-1}\right)$ and $\mathrm{K}_{2} \mathrm{CO}_{3}\left(10 \mathrm{~g} \mathrm{~L}^{-1}\right)$ in water, followed by charring at $c a .150{ }^{\circ} \mathrm{C}$. ${ }^{1} \mathrm{H}$ NMR spectra were recorded at $298 \mathrm{~K}$ on a Bruker AV-400 (400 MHz) spectrometer. Chemical shifts are referenced to $\mathrm{CDCl}_{3}\left(7.26 \mathrm{ppm}, \mathrm{CDCl}_{3}\right)$ or $\mathrm{CD}_{3} \mathrm{OD}$ (3.31 ppm, $\mathrm{CD}_{3} \mathrm{OD}$ ) or $\mathrm{D}_{2} \mathrm{O}$ (4.78 ppm, $\mathrm{D}_{2} \mathrm{O}$ ). ${ }^{13} \mathrm{C}$ NMR APT spectra were recorded at $100 \mathrm{MHz}$, and chemical shifts are referenced to $\mathrm{CDCl}_{3}\left(77.23 \mathrm{ppm}, \mathrm{CDCl}_{3}\right.$ ) or $\mathrm{CD}_{3} \mathrm{OD}$ (48.9 ppm, $\left.\mathrm{CD}_{3} \mathrm{OD}\right) .{ }^{1} \mathrm{H}$ NMR data are reported as though they are first order, and the peak assignments were made by 2D-NMR spectroscopy $\left({ }^{1} \mathrm{H}-{ }^{1} \mathrm{H}\right.$ COSY and HMQC). IR spectra were recorded on a Perkin Elmer Paragon 1000 FT-IR Spectrometer. High resolution mass spectra were recorded by direct injection $(2 \mu \mathrm{L}$ of a $2 \mu \mathrm{M}$ solution in water/acetonitrile $50 / 50(\mathrm{v} / \mathrm{v})$ and $0.1 \%$ formic acid) on a mass spectrometer (Thermo Finnigan LTQ Orbitrap) equipped with an electrospray ion source in positive mode (source voltage $3.5 \mathrm{kV}$, sheath gas flow 10, capillary temperature $250{ }^{\circ} \mathrm{C}$ ) with resolution $R=60000$ at $\mathrm{m} / \mathrm{z} 400$ (mass range $m / z=150-2000)$ and dioctylphthalate $(\mathrm{m} / \mathrm{z}=$ 391.28428) as a "lock mass". The high-resolution mass spectrometer was calibrated prior to measurements with a calibration mixture (Thermo Finnigan). LC-MS analysis was performed on a Jasco HPLC system with a Phenomenex Gemini $3 \mathrm{~lm} \mathrm{C18} 50 \times 4.60 \mathrm{~mm}$ column (detection simultaneously at 214 and $254 \mathrm{~nm}$ ), coupled to a PE Sciex API 165 mass spectrometer with ESI (System A) or a Finnigan Surveyor HPLC system with a Gemini C18 $50 \times 4.60 \mathrm{~mm}$ column (detection at 200-600 nm), coupled to a Finnigan LCQ Advantage Max mass spectrometer with ESI (System B). The applied buffers were $\mathrm{H}_{2} \mathrm{O}, \mathrm{ACN}$ and $1.0 \%$ aq. TFA. The gradient used was $10 \% \rightarrow$ $90 \% \mathrm{ACN} / 0.1 \%$ aq. TFA.

S-2-(2-(2-(Prop-2-ynyloxy)ethoxy)ethoxy)ethyl ethanethioate (3). To a stirred solution of triethylene glycol $(5.30 \mathrm{~g}, 35 \mathrm{mmol})$ and $\mathrm{NaH}(60 \%$ in mineral oil, $1.4 \mathrm{~g}, 35 \mathrm{mmol})$ in THF $(100 \mathrm{~mL})$ at $0{ }^{\circ} \mathrm{C}$ after 30 min was added propargyl bromide $(3.80 \mathrm{~mL}$, $80 \%$ in toluene, $35 \mathrm{mmol}$ ) and stirring was continued for $30 \mathrm{~min}$. The reaction mixture was diluted with ether $(200 \mathrm{~mL})$ and washed with water $(50 \mathrm{~mL})$, brine $(50 \mathrm{~mL})$ and dried over $\mathrm{MgSO}_{4}$. The organic solution was concentrated and the residue was purified by silica gel column chromatography (EtOAc : petroleum ether, elution with $1: 2 \rightarrow 3: 1 \mathrm{v} / \mathrm{v}$ ) to give $2.43 \mathrm{~g}$ of a colorless oil. $1.75 \mathrm{~g}(9.3 \mathrm{mmol})$ of this intermediate was dissolved in $\mathrm{CH}_{2} \mathrm{Cl}_{2}(20 \mathrm{~mL})$, treated with $\mathrm{Et}_{3} \mathrm{~N}(3 \mathrm{~mL})$ and subsequently tosyl chloride $(2.30 \mathrm{~g}, 12.1 \mathrm{mmol})$ was added slowly at $0{ }^{\circ} \mathrm{C}$. The reaction mixture was stirred at $0{ }^{\circ} \mathrm{C}$ for $30 \mathrm{~min}$ and at room temperature for $1 \mathrm{~h}$, then poured onto water $(10 \mathrm{~mL})$, and extracted with ether $(3 \times 20 \mathrm{~mL})$. The organic layer was washed with brine $(10 \mathrm{~mL})$, dried with $\mathrm{MgSO}_{4}$ and concentrated under reduced pressure. The residue was purified by silica gel column chromatography (EtOAc : petroleum ether, elution with $1: 10 \rightarrow 1: 1 \mathrm{v} / \mathrm{v}$ ) to give $2.53 \mathrm{~g}$ of a colorless oil. This intermediate was dissolved in DMF $(20 \mathrm{~mL})$ and treated with KSAc (1.69 g, $14.8 \mathrm{mmol})$. The solution was stirred for $4 \mathrm{~h}$ at $70{ }^{\circ} \mathrm{C}$, and concentrated under diminished pressure. The remaining reddish oil was purified by silica gel column chromatography (EtOAc : petroleum ether, elution with $1: 10$ to $4: 1$ $\mathrm{v} / \mathrm{v})$ to give $3(1.5 \mathrm{~g}, 25 \%$ yield in three steps) as a colorless oil; $R_{\mathrm{f}} 0.55$ (EtOAc : petroleum ether $\left.1: 2 \mathrm{v} / \mathrm{v}\right) ;{ }^{1} \mathrm{H}$ NMR $(400 \mathrm{MHz}$, $\left.\mathrm{CDCl}_{3}\right) \delta 4.21(\mathrm{~d}, J=2.4 \mathrm{~Hz}, 2 \mathrm{H}), 3.72-3.63(\mathrm{~m}, 8 \mathrm{H}), 3.60$ (t, $J=6.4 \mathrm{~Hz}, 2 \mathrm{H}), 3.10(\mathrm{t}, J=6.4 \mathrm{~Hz}, 2 \mathrm{H}), 2.44(\mathrm{t}, J=$ $2.4 \mathrm{~Hz}, 1 \mathrm{H}), 2.34(\mathrm{~s}, 3 \mathrm{H}) ;{ }^{13} \mathrm{C}$ NMR $\left(100 \mathrm{MHz}, \mathrm{CDCl}_{3}\right)$ $\delta 195.74,79.83,74.71,70.73,70.65,70.48,69.94,69.28,58.59$, $30.76,29.02$; IR neat $\left(\mathrm{cm}^{-1}\right) 3251.9,2867.7,1686.1,1353.5$, 1096.7, 1032.7, 626.2; HRMS $\mathrm{m} / \mathrm{z}$ calculated for $\left(\mathrm{M}+\mathrm{H}^{+}\right)$ $\mathrm{C}_{11} \mathrm{H}_{19} \mathrm{O}_{4} \mathrm{~S}$ 2479.0926. Found: 2479.0999.

Ethyl 5-azido-4-oxopentanoate. To a solution of ethyl 5-bromo4-oxopentanoate ${ }^{16}(0.35 \mathrm{~g}, 1.57 \mathrm{mmol})$ in THF $(5 \mathrm{~mL})$ was added a solution of $\mathrm{NaN}_{3}(0.20 \mathrm{~g}, 3.14 \mathrm{mmol})$ in $\mathrm{H}_{2} \mathrm{O}(3 \mathrm{~mL})$ at $0{ }^{\circ} \mathrm{C}$. Stirring was continued for $1 \mathrm{~h}$ at room temperature and then the reaction mixture was diluted with $\mathrm{H}_{2} \mathrm{O}(10 \mathrm{~mL})$ and extracted with EtOAc $(3 \times 10 \mathrm{~mL})$. The organic layer was washed with brine $(10 \mathrm{~mL})$, dried over $\mathrm{MgSO}_{4}$ and concentrated under reduced pressure. The residue was purified by silica gel column chromatography (EtOAc : petroleum ether $1: 20 \mathrm{v} / \mathrm{v}$ ) to give ethyl 5 -azido-4-oxopentanoate $(0.27 \mathrm{~g}, 95 \%)$ as a slightly yellow oil; $R_{\mathrm{f}} 0.5$ (EtOAc: petroleum ether $1: 8 \mathrm{v} / \mathrm{v}$ ); ${ }^{1} \mathrm{H}$ NMR $\left(400 \mathrm{MHz}, \mathrm{CDCl}_{3}\right) \delta 4.13(\mathrm{q}, J=7.2 \mathrm{~Hz}, 2 \mathrm{H}), 4.04(\mathrm{~s}, 2 \mathrm{H})$, 
$2.72(\mathrm{ddd}, J=8.8,6.8,1.7 \mathrm{~Hz}, 2 \mathrm{H}), 2.66$ (ddd, $J=8.8,6.8,1.7$ $\mathrm{Hz}, 2 \mathrm{H}), 1.26$ (t, $J=7.2,3 \mathrm{H}) ;{ }^{13} \mathrm{C} \mathrm{NMR}\left(100 \mathrm{MHz}, \mathrm{CDCl}_{3}\right.$ ) $\delta$ 203.08, 172.31, 60.89, 57.49, 34.40, 27.85, 14.11; IR neat $\left(\mathrm{cm}^{-1}\right)$ 2984.1, 2103.4, 1727.5, 1203.0; HRMS $\mathrm{m} / \mathrm{z}$ calculated for $\left(\mathrm{M}+\mathrm{H}^{+}\right) \mathrm{C}_{7} \mathrm{H}_{12} \mathrm{~N}_{3} \mathrm{O}_{3}$ 186.0800. Found: 186.2195.

Ethyl 4-oxo-5-(6-(5-((3aS,4S,6aR)-2-oxohexahydro-1 $\underline{H}$-thieno [3,4-d]imidazol-4-yl)pentanamido)hexanamido)pentanoate (5). Biotin-AHA-NHS $4^{17}(0.1 \mathrm{~g}, 0.22 \mathrm{mmol})$ and ethyl 5-azido-4oxopentanoate (49 $\mathrm{mg}, 0.26 \mathrm{mmol}$ ) were dissolved in methanol $(20 \mathrm{~mL})$. To this solution was added $10 \% \mathrm{Pd} / \mathrm{C}(5 \mathrm{mg})$ and stirring was continued for $4 \mathrm{~h}$ under a hydrogen atmosphere. The solution was concentrated and the residue was purified by silica gel column chromatography $\left(\mathrm{CH}_{2} \mathrm{Cl}_{2}: \mathrm{CH}_{3} \mathrm{OH}\right.$, elution with $30: 1 \rightarrow 7: 1, \mathrm{v} / \mathrm{v})$ to give compound $\mathbf{5}(80 \mathrm{mg}, 73 \%)$ as a white amorphous solid; $R_{\mathrm{f}} 0.19 \quad\left(\mathrm{CH}_{2} \mathrm{Cl}_{2}: \mathrm{CH}_{3} \mathrm{OH} \quad 10: 1 \quad \mathrm{v} / \mathrm{v}\right)$; ${ }^{1} \mathrm{H}$ NMR (400 MHz, CD 3 OD) $\delta 4.52(\mathrm{dd}, J=7.8,5.0 \mathrm{~Hz}, 1 \mathrm{H})$, 4.33 (dd, $J=7.8,4.5 \mathrm{~Hz}, 1 \mathrm{H}), 4.13$ (q, $J=7.1 \mathrm{~Hz}, 2 \mathrm{H}), 4.09$ (s, $2 \mathrm{H}), 3.26-3.18(\mathrm{~m}, 1 \mathrm{H}), 2.96(\mathrm{dd}, J=12.7,5.0 \mathrm{~Hz}, 1 \mathrm{H})$, $2.79(\mathrm{t}, J=6.4 \mathrm{~Hz}, 2 \mathrm{H}), 2.73(\mathrm{~d}, J=12.7 \mathrm{~Hz}, 1 \mathrm{H}), 2.61(\mathrm{t}, J=$ $6.4 \mathrm{~Hz}, 1 \mathrm{H}), 2.30$ (t, $J=7.4 \mathrm{~Hz}, 1 \mathrm{H}), 2.22(\mathrm{t}, J=7.3 \mathrm{~Hz}, 1 \mathrm{H})$, 1.78-1.39 (m, $14 \mathrm{H}), 1.26(\mathrm{t}, J=7.1 \mathrm{~Hz}, 3 \mathrm{H}) ;{ }^{13} \mathrm{C} \mathrm{NMR}$ $\left(100 \mathrm{MHz}, \mathrm{CD}_{3} \mathrm{OD}\right) \delta 205.03,175.04,174.58,172.95,164.70$, $61.99,60.34,60.23,55.62,48.33,39.67,38.80,35.42,35.18$, $33.83,28.69,28.38,28.10,27.37,26.08,25.52,25.11,13.10$; IR neat $\left(\mathrm{cm}^{-1}\right) 3314.7,2936.0,1710.0,1640.8,1538.0,1423.8$, 1197.5. HRMS $m / z$ calculated for $\left(\mathrm{M}+\mathrm{H}^{+}\right) \mathrm{C}_{23} \mathrm{H}_{39} \mathrm{~N}_{4} \mathrm{O}_{6} \mathrm{~S}$ 499.2512. Found: 499.2582.

4-Oxo-5-(6-(5-((3aS,4S,6aR)-2-oxohexahydro-1H-thieno[3,4-d]imidazol-4-yl)pentanamido)hexanamido)pentanoic acid (6). To a solution of ester 5 ( $80 \mathrm{mg}, 0.16 \mathrm{mmol})$ in methanol $(10 \mathrm{~mL})$ was added $\mathrm{NaOH}(2 \mathrm{M}, 1.5 \mathrm{~mL})$. The solution was stirred at room temperature for $3 \mathrm{~h}$, and then adjusted to $\mathrm{pH} 5$ by adding $\mathrm{HCl}$ (2 M). The solution was concentrated under reduced pressure and after adding $\mathrm{H}_{2} \mathrm{O}(5 \mathrm{~mL})$ sonicated for $5 \mathrm{~min}$ at room temperature. The resulting white solid was filtered to obtain the product $6(65 \mathrm{mg}, 87 \%)$ without the need for further purification; ${ }^{1} \mathrm{H}$ NMR (400 MHz, DMSO) $\delta 12.15(\mathrm{~s}, 1 \mathrm{H}), 8.11(\mathrm{~s}, 1 \mathrm{H})$, $7.74(\mathrm{~s}, 1 \mathrm{H}), 6.44(\mathrm{~s}, 1 \mathrm{H}), 6.37(\mathrm{~s}, 1 \mathrm{H}), 4.31(\mathrm{~s}, 1 \mathrm{H}), 4.13$ (s, $1 \mathrm{H}), 3.92(\mathrm{~s}, 2 \mathrm{H}), 3.34(\mathrm{~s}, 4 \mathrm{H}), 3.10-2.04(\mathrm{~m}, 13 \mathrm{H})$, $1.60-1.26(\mathrm{~m}, 12 \mathrm{H}) ;{ }^{13} \mathrm{C}$ NMR (100 MHz, DMSO) $\delta 206.19$, $174.11,172.91,172.23,163.17,61.49,59.64,55.89,48.77$, $40.37,38.74,35.67,35.45,34.43,29.44,28.68,28.49,27.87$, $26.55,25.79,25.43$; IR neat $\left(\mathrm{cm}^{-1}\right)$ 3315.7, 2939.9, 1699.8, 1638.9, 1537.8, 1264.0; HRMS $m / z$ calculated for $\left(\mathrm{M}+\mathrm{H}^{+}\right)$ $\mathrm{C}_{21} \mathrm{H}_{35} \mathrm{~N}_{4} \mathrm{O}_{6} \mathrm{~S}$ 471.2199. Found: 471.2272.

$\mathrm{N}$-(2-(2-(2-Azidoethoxy)ethoxy)ethyl)- $\mathrm{N}$-(4-hydroxy-3,5-diisopropylbenzyl)acetamide (7). 1,2-Bis(2-azidoethoxy)ethane $(0.24 \mathrm{~g}, 1.29 \mathrm{mmol})$ was dissolved in a mixture of THF and $\mathrm{H}_{2} \mathrm{O}(5 \mathrm{~mL}, 4: 1 \mathrm{v} / \mathrm{v})$. To this solution was added $\mathrm{PPh}_{3}(0.34 \mathrm{~g}$, $1.29 \mathrm{mmol}$ ) and stirring was continued for $17 \mathrm{~h}$. The solution was diluted with $\mathrm{H}_{2} \mathrm{O}(10 \mathrm{~mL})$ and washed with ether $(2 \times$ $10 \mathrm{~mL}$ ). The water layer was concentrated under reduced pressure and the crude product was dissolved in methanol $(10 \mathrm{~mL})$. The reaction mixture was cooled to $0{ }^{\circ} \mathrm{C}$ and 4-hydroxy-3,5-diisopropylbenzaldehyde (0.16 g, $0.77 \mathrm{mmol})$ was added. The solution was adjusted to $\mathrm{pH} 8$ with the aid of a $5 \mathrm{M} \mathrm{NaOH}$ solution. After stirring for $2 \mathrm{~h}$ at room temperature, the reaction mixture was cooled to $-10{ }^{\circ} \mathrm{C}$ and $\mathrm{NaBH}_{4}(30 \mathrm{mg}$, $0.77 \mathrm{mmol}$ ) was added. The reaction mixture was stirred for $30 \mathrm{~min}$, then allowed to warm to room temperature and stirring was continued for another $30 \mathrm{~min}$. The reaction mixture was then adjusted to $\mathrm{pH} 6$ by adding acetic acid. To the solution was added acetic anhydride $(5 \mathrm{~mL})$ and stirring was continued for $2 \mathrm{~h}$. The reaction mixture was diluted with ether $(20 \mathrm{~mL})$ and washed with $1 \mathrm{M} \mathrm{NaOH}(5 \mathrm{~mL})$, water $(5 \mathrm{~mL})$, brine $(5 \mathrm{~mL})$ and dried over $\mathrm{MgSO}_{4}$. The organic layer was concentrated under reduced pressure and the residue was purified by silica gel column chromatography (EtOAc: petroleum ether, elution with $1: 2 \rightarrow 3: 1 \mathrm{v} / \mathrm{v})$ to give compound $7(0.27 \mathrm{~g}, 87 \%)$ as a colorless oil; $R_{\mathrm{f}} 0.29$ (EtOAc: petroleum ether $\left.1: 1 \mathrm{v} / \mathrm{v}\right) ;{ }^{1} \mathrm{H}$ NMR $\left(400 \mathrm{MHz}, \mathrm{CDCl}_{3}\right) \delta 6.93,6.83(2 \times \mathrm{s}, 2 \mathrm{H}), 5.52,5.38(2 \times \mathrm{s}$, $1 \mathrm{H}), 4.58(\mathrm{~s}, 2 \mathrm{H}), 3.76-3.72(\mathrm{~m}, 1 \mathrm{H}), 3.68-3.52(\mathrm{~m}, 9 \mathrm{H})$, 3.41-3.36 (m, $2 \mathrm{H}), 3.18$ (sept, $J=7.0 \mathrm{~Hz}, 2 \mathrm{H}), 2.20,2.15(2 \times$ $\mathrm{s}, 2 \mathrm{H}), 1.23(\mathrm{~d}, J=7.0 \mathrm{~Hz}, 12 \mathrm{H}) ;{ }^{13} \mathrm{C} \mathrm{NMR}\left(100 \mathrm{MHz}, \mathrm{CDCl}_{3}\right)$ $\delta 171.27$ (b), 171.12 (a), 149.45 (b), 149.39 (a), 134.53 (2 C, b), 134.07 (2 C, a), 129.17(a), 128.26 (b), 123.45 (2 C, a), 121.32 (2 C, b), 70.98, 70.87, 70.75 (b), 70.70 (a), 70.42 (b), 70.40(a), 69.39 (a), 69.22 (b), 53.63 (a), 51.00 (b), 47.81 (a), 45.99 (b), 27.02 (2 C), 22.68 (4 C), 21.66 (a), 21.63 (b); $R_{\mathrm{f}} 0.29$ (EtOAc: petroleum ether $1: 1 \mathrm{v} / \mathrm{v})$; IR neat $\left(\mathrm{cm}^{-1}\right) 3342.1,2960.3,2111.9$, $1624.3,1471.9,1287.7,1202.7,1123.5,784.1$. HRMS $\mathrm{m} / z$ calculated for $\left(\mathrm{M}+\mathrm{H}^{+}\right) \mathrm{C}_{21} \mathrm{H}_{35} \mathrm{~N}_{4} \mathrm{O}_{4}$ 407.2580. Found: 407.2649.

4-((N-(2-(2-(2-Azidoethoxy)ethoxy)ethyl)acetamido)methyl)-2,6diisopropylphenyl 4-oxo-5-(6-(5-( (3a $S, 4 S, 6 \mathrm{a} R)-2-0 x 0 h e x a h y d r o-$ $1 H$-thieno[3,4- $d]$ imidazol-4-yl)pentanamido)hexanamido)pentanoate (2). Acid 6 (18 mg, $0.038 \mathrm{mmol})$, phenol 7 (31 mg, $0.078 \mathrm{mmol})$ and EDC (15 mg, $0.078 \mathrm{mmol})$ were taken up in DMF (3 mL). To the suspension was added DMAP (5 mg, $0.04 \mathrm{mmol}$ ) and stirring was continued for $16 \mathrm{~h}$ at $70{ }^{\circ} \mathrm{C}$. The reaction mixture was concentrated under reduced pressure and the residue was purified by silica gel column chromatography $\left(\mathrm{CH}_{2} \mathrm{Cl}_{2}: \mathrm{CH}_{3} \mathrm{OH}\right.$, elution with $\left.30: 1 \rightarrow 7: 1 \mathrm{v} / \mathrm{v}\right)$ to give product $2(4.8 \mathrm{mg}, 15 \%)$ as a colorless oil; $R_{\mathrm{f}} 0.6\left(\mathrm{CH}_{2} \mathrm{Cl}_{2}\right.$ : $\left.\mathrm{CH}_{3} \mathrm{OH} 8: 1 \mathrm{v} / \mathrm{v}\right) ;{ }^{1} \mathrm{H}$ NMR (400 MHz, CD $\left.{ }_{3} \mathrm{OD}\right) \delta 7.07,6.99$ $(2 \times \mathrm{s}, 2 \mathrm{H}), 4.72,4.63(2 \times \mathrm{s}, 2 \mathrm{H}), 4.48(\mathrm{dd}, J=7.9,4.7 \mathrm{~Hz}$, $1 \mathrm{H}), 4.29$ (dd, $J=7.9,4.3 \mathrm{~Hz}, 1 \mathrm{H}), 4.08$ (s, $2 \mathrm{H}), 3.66-3.52$ (m, 8 H), 3.37-3.34 (m, $2 \mathrm{H}), 3.22-3.16$ (m, 3 H), 2.99-2.88 $(\mathrm{m}, 5 \mathrm{H}), 2.70(\mathrm{~d}, J=12.7 \mathrm{~Hz}, 1 \mathrm{H}), 2.28$ (t, $J=7.4 \mathrm{~Hz}, 2 \mathrm{H})$, 2.24, $2.12(2 \times \mathrm{s}, 2 \mathrm{H}), 2.19(\mathrm{t}, J=7.3 \mathrm{~Hz}, 2 \mathrm{H}), 1.75-1.36(\mathrm{~m}$, $14 \mathrm{H}), 1.60(\mathrm{~d}, J=6.5 \mathrm{~Hz}, 12 \mathrm{H}) ;{ }^{13} \mathrm{C} \mathrm{NMR}(100 \mathrm{MHz}$, $\left.\mathrm{CD}_{3} \mathrm{OD}\right) \delta$ 206.04, 176.50, 176.01, 174.16, 173.40, 166.12, 146.17 (a), 146.13 (b), 134.54 (2 C, a), 142.07 (2 C, b), 137.23 (b), 126.53 (a), 124.66 (2 C, b), 122.98 (2 C, a), 71.79, 71.67, 71.53 (b), 71.51 (a), 71.23 (b), 71.20 (a), 70.32 (a), 70.12 (b), $63.42,61.65,57.06,54.27$ (a), 51.82, 49.80 (b), 49.71 (a), 47.16 (b), 41.10, 40.23, 36.85, 36.60, 35.16, 34.72, 30.12, 29.82, 29.53, 28.63 (4 C), 27.51, 26.96, 26.57, 21.85 (2 C), 21.75; IR neat $\left(\mathrm{cm}^{-1}\right) 3290.0,2926.3,2109.1,1695.9,1653.9,1559.9$, 1458.0, 1142.0, 668.0. HRMS $\mathrm{m} / \mathrm{z}$ calculated for $\left(\mathrm{M}+\mathrm{H}^{+}\right)$ $\mathrm{C}_{42} \mathrm{H}_{67} \mathrm{~N}_{8} \mathrm{O}_{9} \mathrm{~S}$ 859.4673. Found: 859.4751.

\section{Bacterial strain culture conditions}

For the preparation of culture stocks, the Bacillus sp. H1L Y85 54728 was grown in a nutrient broth at $30{ }^{\circ} \mathrm{C}$ for $24 \mathrm{~h}$. A colony 
was transferred from the solid medium to a $3 \mathrm{~mL}$ tryptone soy broth and incubated for $24 \mathrm{~h}$ at $200 \mathrm{rpm}$ and $30{ }^{\circ} \mathrm{C}$. The culture was diluted $1: 1$ with sterile $20 \%$ glycerol and stored at $-80{ }^{\circ} \mathrm{C}$. The seed culture $(0.1 \mathrm{~mL})$ was inoculated into $50 \mathrm{~mL}$ mersacidin production medium $2 \times \mathrm{BPM}\left(\left(\mathrm{NH}_{4}\right)_{2} \mathrm{SO}_{4}(50 \mathrm{mM}), \mathrm{MgSO}_{4}\right.$ (2 mM), $\mathrm{CaCl}_{2}(1 \mathrm{mM}), \mathrm{FeSO}_{4}(0.35 \mathrm{mM}), \mathrm{MnSO}_{4}(1 \mathrm{mM})$, Tris-maleate buffer $\mathrm{pH} 7(0.1 \mathrm{M})$, glucose $(0.4 \mathrm{M})$, potassium phosphate buffer $\mathrm{pH} 7(0.04 \mathrm{M}))$ in a $200 \mathrm{~mL}$ spring flask and was shaken at $30{ }^{\circ} \mathrm{C}$ and $200 \mathrm{rpm}$ for $4-5$ days. The culture $(50 \mathrm{~mL})$ was centrifuged at $5000 \mathrm{rpm}$ for $3 \times 10 \mathrm{~min}$. The supernatant was collected and lyophilized. The foamy residue was treated with methanol $(50 \mathrm{~mL})$ and sonicated for $10 \mathrm{~min}$. The suspension was centrifuged and the supernatant was collected and concentrated to a small volume and applied on a Sephadex LH 20 column using methanol as an eluent. The high molecular weight fractions were collected, concentrated under reduced pressure to give a sample of $8 \mathrm{mg}$. LC/MS analysis (Scheme 3) showed that mersacidin $\left(\mathrm{C}_{80} \mathrm{H}_{120} \mathrm{~N}_{20} \mathrm{O}_{21} \mathrm{~S}_{4}\right.$ calculated mass 1824.78) was present in the sample in a small amount, indicated by ions $m / z$ 913.27 $\mathrm{Da}\left[\mathrm{M}+2 \mathrm{H}^{+}\right]^{2+}$ and 1826.47 $\mathrm{Da}\left[\mathrm{M}+\mathrm{H}^{+}\right]^{+}$, retention time $7.18 \mathrm{~min}$.

\section{Protocol for the two-step labeling, pull-down, release and identification of the lantibiotic mersacidin from culture}

Step A: opening of the thioether linkage(s) and labeling. To the obtained cultured sample $(3 \mathrm{mg}$ ) in a $0.5 \mathrm{~mL}$ Eppendorf vial were added thio-alkyne $3(2 \mathrm{mg}, 8.1 \mu \mathrm{mol}), \mathrm{H}_{2} \mathrm{O}(10 \mu \mathrm{L})$ and EtOH $(20 \mu \mathrm{L})$. The reaction mixture was carefully flushed with argon for 2 min and a $1 \mathrm{M} \mathrm{NaOH}$ solution $(8.1 \mu \mathrm{L})$ was added. The reaction mixture was shaken vigorously (vortex) and stirred at $50{ }^{\circ} \mathrm{C}$ for $1 \mathrm{~h}$ and subsequently quenched with a $1 \mathrm{M}$ acetic acid solution $(8.1 \mu \mathrm{L})$. The reaction mixture was shaken vigorously (vortex) and centrifuged for $3 \mathrm{~min}$ at $5000 \mathrm{rpm}$ using an Eppendorf centrifuge. The supernatant was discarded to obtain a white precipitate.

Step B: reduction of $S-S$ linkages and reaction of the free thiols with iodoacetamide. The white precipitate was dissolved in EtOH and $\mathrm{H}_{2} \mathrm{O}(40 \mu \mathrm{L}, 1: 1 \mathrm{v} / \mathrm{v})$ and a solution of DTT $(60 \mu \mathrm{L})$ as a $0.2 \mathrm{M}$ solution in a $1: 1$ mixture of EtOH and $50 \mathrm{mM}$ aq. $\left(\mathrm{NH}_{4}\right)_{2} \mathrm{CO}_{3}$ was added. The Eppendorf vial was incubated for $30 \mathrm{~min}$ at $37{ }^{\circ} \mathrm{C}$ using a water bath. Subsequently, iodoacetamide $(60 \mu \mathrm{L})$ as a $0.6 \mathrm{M}$ solution in a $1: 1$ mixture of EtOH and $50 \mathrm{mM}$ aq. $\left(\mathrm{NH}_{4}\right)_{2} \mathrm{CO}_{3}$ was added and the reaction mixture was shaken for $30 \mathrm{~min}$ at room temperature in the dark. The reaction mixture was dialysed with MWCO 1200 cellulose tubing in a mixture of EtOH and $\mathrm{H}_{2} \mathrm{O}(1: 1, \mathrm{v} / \mathrm{v})$ for $24 \mathrm{~h}$. The resulting solution was collected and concentrated under reduced pressure in an Eppendorf centrifuge.

Step C: click reaction and pull-down using magnetic streptavidin beads. The residue was dissolved in a mixture of $t$-butanol and ethanol $(10 \mu \mathrm{L}, 2: 1 \mathrm{v} / \mathrm{v})$. The solution was flushed carefully with argon and a solution of the biotin probe $2(0.5 \mathrm{mg}$, $0.58 \mu \mathrm{mol})$ in $t$-butanol and ethanol $(5 \mu \mathrm{L}, 2: 1 \mathrm{v} / \mathrm{v})$ was added. To the stirred reaction mixture were added $\mathrm{CuSO}_{4}(0.09 \mathrm{mg}$, $0.58 \mu \mathrm{mol})$ and sodium ascorbate $(0.12 \mathrm{mg}, 0.58 \mu \mathrm{mol})$. Stirring was continued for $16 \mathrm{~h}$ followed by concentration of the reaction mixture. The residue was dissolved in methanol $(20 \mu \mathrm{L})$ and pull-down (PD) buffer (50 mM Tris $\cdot \mathrm{HCl} \mathrm{pH} \mathrm{7.5,} 150 \mathrm{mM} \mathrm{NaCl}$ ) (1 $\mathrm{mL})$ to afford a clear solution. The solution was incubated with $50 \mu \mathrm{L}$ pre-washed MyOne T1 Streptavidin grafted magnetic beads (Invitrogen) at $4{ }^{\circ} \mathrm{C}$ with vigorous shaking for $1 \mathrm{~h}$. The beads were stringently washed with $300 \mu \mathrm{L}$ PD buffer with $0.1 \%$ SDS, $2 \times 300 \mu \mathrm{L}$ PD buffer, $2 \times 300 \mu \mathrm{L}$ wash buffer I, $2 \times 300 \mu \mathrm{L}$ wash buffer II and $2 \times 300 \mu \mathrm{L}$ water.

Step D: release from the beads and analysis. To the biotin captured magnetic beads was added hydrazine $(300 \mu \mathrm{L}, 100 \mu \mathrm{M})$ and the sample was shaken at $37{ }^{\circ} \mathrm{C}$ for $2 \mathrm{~h}$ (or at room temperature for $17 \mathrm{~h}$ ). The supernatant was removed and lyophilized to give a white powder, which was dissolved in a mixture of $t$-butanol, acetonitrile and water $(40 \mu \mathrm{L}, 1: 1: 1, \mathrm{v} / \mathrm{v})$ that was analyzed with LC/MS. From this sample the modified mersacidin product was identified having a retention time of $9.05 \mathrm{~min}$ and $m / z 1239.93 \mathrm{Da}\left[\mathrm{M}+\mathrm{HSA}+\mathrm{Ac}+\text { biotin-C }+2 \mathrm{H}^{+}\right]^{2+}$ (Scheme 3).

\section{Analysis of the protocol}

Opening of the thioether linkage(s) and labeling. A mixture of pure mersacidin $(0.25 \mathrm{mg}, 0.137 \mu \mathrm{mol})$ kindly provided by the company Novacta and thio-alkyne $3(1.01 \mathrm{mg}, 4.11 \mu \mathrm{mol}, 30$ equiv.), $\mathrm{H}_{2} \mathrm{O}(10 \mu \mathrm{L})$, EtOH $(10 \mu \mathrm{L})$ in a $0.5 \mathrm{~mL}$ Eppendorf vial was carefully flushed with argon for $2 \mathrm{~min}$ and $1 \mathrm{M} \mathrm{NaOH}$ (4.1 $\mu \mathrm{L}, 4.11 \mu \mathrm{mol}, 30$ equiv.) was added. The mixture was stirred at $50{ }^{\circ} \mathrm{C}$ for $1 \mathrm{~h}$. A solution of $1 \mathrm{M}$ acetic acid $(4.1 \mu \mathrm{L})$ was added to the reaction mixture. The solution was vortexed and centrifuged. The supernatant was discarded and the white precipitate was dissolved in $\mathrm{EtOH}$ and $\mathrm{H}_{2} \mathrm{O}(40 \mu \mathrm{L}, 1: 1, \mathrm{v} / \mathrm{v})$. The reaction mixture was analyzed by LC/MS. From the spectrum shown in Fig. S1, $\dagger$ mersacidin was modified at one, two and three positions in the sequence. This is indicated by the ions $m / z 1037.00 \mathrm{Da}\left[\mathrm{M}+\mathrm{HSA}+\mathrm{Ac}+2 \mathrm{H}^{+}\right]^{2+}, \mathrm{C}_{91} \mathrm{H}_{140} \mathrm{~N}_{20} \mathrm{O}_{25} \mathrm{~S}_{5}{ }^{2+}$, calculated mass 1036.44, $1139.00 \mathrm{Da}[\mathrm{M}+2 \mathrm{HSA}+\mathrm{Ac}+$ $\left.2 \mathrm{H}^{+}\right]^{2+} \quad \mathrm{C}_{100} \mathrm{H}_{156} \mathrm{~N}_{20} \mathrm{O}_{28} \mathrm{~S}_{6}{ }^{2+}$, calculated mass 1138.48 and $1240.67 \mathrm{Da}\left[\mathrm{M}+3 \mathrm{HSA}+\mathrm{Ac}+2 \mathrm{H}^{+}\right]^{2+}, \mathrm{C}_{109} \mathrm{H}_{172} \mathrm{~N}_{20} \mathrm{O}_{31} \mathrm{~S}_{7}{ }^{2+}$, calculated mass 1240.52 , within $7.33-9.38$ min retention times. The modified mersacidin product $\left[\mathrm{M}+\mathrm{HSA}+\mathrm{Ac}+2 \mathrm{H}^{+}\right]^{2+}$ was sequenced to show that the modification site is at position 13 in the sequence (Fig. S2 $\uparrow$ ). From the LC/MS data it was also observed that the reactive compound $\mathbf{1}$, which is formed in situ via deacetylation of $\mathbf{3}$ in the strong basic medium, also formed a dimer during the reaction conditions (ion $m / z$ 406.60 Da, $\mathrm{C}_{18} \mathrm{H}_{31} \mathrm{O}_{6} \mathrm{~S}_{2}{ }^{+}$, calculated mass 407.15). To exclude labeling via the formation of $\mathrm{S}-\mathrm{S}$ linkages we included a reduction and alkylation step in our protocol.

Reduction of S-S linkages and reaction of the free thiols with iodoacetamide. The above obtained reaction mixture was treated with a solution of $0.2 \mathrm{M} \mathrm{DTT}(40 \mu \mathrm{L})$ in a $1: 1$ mixture of EtOH and $50 \mathrm{mM}$ aq. $\left(\mathrm{NH}_{4}\right)_{2} \mathrm{CO}_{3}$ for $30 \mathrm{~min}$ at $37^{\circ} \mathrm{C}$, and was alkylated with iodoacetamide $(40 \mu \mathrm{L}, 0.6 \mathrm{M}$ in a $1: 1$ mixture of EtOH and $50 \mathrm{mM}$ aq. $\left.\left(\mathrm{NH}_{4}\right)_{2} \mathrm{CO}_{3}\right)$ for $30 \mathrm{~min}$ at room temperature in the dark. The mixture was dialysed with MWCO 1200 cellulose tubing in a mixture of EtOH and $\mathrm{H}_{2} \mathrm{O}(1: 1, \mathrm{v} / \mathrm{v})$ for $24 \mathrm{~h}$. The resulting solution was collected and analyzed with 
LC/MS (Fig. S3 $\dagger$ ). The spectrum showed that the thiol groups of the thioether opened and modified mersacidin reacted with the iodoacetamide as indicated by the ions $\mathrm{m} / \mathrm{z} 1065.80 \mathrm{Da}$ $\left[\mathrm{M}+\mathrm{HSA}+\mathrm{Ac}+\mathrm{IAA}+2 \mathrm{H}^{+}\right]^{2+}, \mathrm{C}_{93} \mathrm{H}_{143} \mathrm{~N}_{21} \mathrm{O}_{26} \mathrm{~S}_{5}{ }^{2+}$, calculated mass 1064.95, rt 7.96 min; 1167.73 Da [M + 2HSA + Ac $\left.+\mathrm{IAA}+2 \mathrm{H}^{+}\right]^{2+}, \mathrm{C}_{102} \mathrm{H}_{159} \mathrm{~N}_{21} \mathrm{O}_{29} \mathrm{~S}_{6}{ }^{2+}$, calculated mass 1166.99, rt $8.54 \mathrm{~min}$. The product with ion 1037.40 $\mathrm{Da}$ [M + HSA + Ac $\left.+2 \mathrm{H}^{+}\right]^{2+}$, rt 8.25, $8.48 \mathrm{~min}$, did not change.

Click reaction. Pure mersacidin $(2.1 \mathrm{mg}, 1.15 \mu \mathrm{mol})$ was labeled as described using compound 3 (8.5 mg, $34.5 \mu \mathrm{mol})$ under basic conditions $1 \mathrm{M} \mathrm{NaOH}(34.5 \mu \mathrm{mol})$, reduced with $0.2 \mathrm{M} \mathrm{DTT}(400 \mu \mathrm{L})$ in a $1: 1$ mixture of EtOH and $50 \mathrm{mM}$ aq. $\left(\mathrm{NH}_{4}\right)_{2} \mathrm{CO}_{3}$, alkylated with iodoacetamide $(400 \mu \mathrm{L}) 0.6 \mathrm{M}$ in a $1: 1$ mixture of EtOH and $50 \mathrm{mM}$ aq. $\left(\mathrm{NH}_{4}\right)_{2} \mathrm{CO}_{3}$ and dialysed. The obtained reaction mixture was dissolved in a mixture of $t$-butanol and ethanol $(30 \mu \mathrm{L}, 2: 1, \mathrm{v} / \mathrm{v})$. The solution was flushed carefully with argon for $2 \mathrm{~min}$ and a solution of the biotin probe $2(0.98 \mathrm{mg}, 1.15 \mu \mathrm{mol})$ in $t$-butanol and ethanol $(10 \mu \mathrm{L}, 2: 1 \mathrm{v} / \mathrm{v}), \mathrm{CuSO}_{4}(0.18 \mathrm{mg}, 1.15 \mu \mathrm{mol})$ and sodium ascorbate $(0.23 \mathrm{mg}, 1.15 \mu \mathrm{mol})$ were added. The reaction mixture was stirred for $16 \mathrm{~h}$ at room temperature and analyzed by LC/MS. The corresponding 2-step labeled products are indicated by ions $m / z 1466.53 \mathrm{Da}[\mathrm{M}+\mathrm{HSA}+\mathrm{Ac}+$ Biotin + $\left.2 \mathrm{H}^{+}\right]^{2+}, \mathrm{C}_{133} \mathrm{H}_{206} \mathrm{~N}_{28} \mathrm{O}_{34} \mathrm{~S}_{6}{ }^{2+}$, calculated mass 1465.67 , with $\mathrm{rt}$ $8.31 \mathrm{~min}, 1494.60 \mathrm{Da}[\mathrm{M}+\mathrm{HSA}+\mathrm{Ac}+\mathrm{IAA}+$ Biotin + $\left.2 \mathrm{H}^{+}\right]^{2+}, \mathrm{C}_{135} \mathrm{H}_{209} \mathrm{~N}_{29} \mathrm{O}_{35} \mathrm{~S}_{6}{ }^{2+}$, calculated mass 1494.18 , with $\mathrm{rt}$ 7.94 min (Fig. S4†).

Reactivity of the cleavable linker. The biotin labeled mersacidin dissolved in methanol $(21 \mu \mathrm{L})$ was divided over six $0.5 \mathrm{~mL}$ Eppendorf vials and two different concentrations of hydrazine $(0.05 \mathrm{M}, 0.1 \mathrm{M})$ were added and each of the two sets was stirred at room temperature, $37{ }^{\circ} \mathrm{C}$ and $50{ }^{\circ} \mathrm{C}$, respectively. The reactions were monitored by LC/MS. It was found that the samples using $0.1 \mathrm{M}$ hydrazine, at room temperature for $17 \mathrm{~h}$ or at $37^{\circ} \mathrm{C}$ for $4 \mathrm{~h}$, gave complete conversion, as shown in Fig. S5.† The cleaved products were found to be ions $\mathrm{m} / \mathrm{z} 1239.93 \mathrm{Da}$ $\left[\mathrm{M}+\mathrm{HSA}+\mathrm{Ac}+\text { biotin-C }+2 \mathrm{H}^{+}\right]^{2+}$ with $\mathrm{rt} 9.00 \mathrm{~min}, 1268.93$ $\mathrm{Da}\left[\mathrm{M}+\mathrm{HSA}+\mathrm{Ac}+\mathrm{IAA}+\text { biotin-C }+2 \mathrm{H}^{+}\right]^{2+}$ with $\mathrm{rt}$ $8.53 \mathrm{~min}$.

\section{Acknowledgements}

We are very grateful to Mike Dawson for providing mersacidin and for discussion, and to Mervyn Bibb for discussion. This research was funded by the Dutch Technical Science Foundation
(STW-Genbiotics program GenExpand) and by the Netherlands Genomics Initiative (NGI).

\section{Notes and references}

1 (a) D. J. Payne, M. N. Gwynn, D. J. Holmes and D. L. Pompliano, Nat. Rev. Drug Discovery, 2007, 6, 39-40; (b) D. J. Cooper and D. Shlaes, Nature, 2011, 472, 32-32.

2 G. L. Challis and D. A. Hopwood, Proc. Natl. Acad. Sci. U. S. A., 2003, 100, $14555-14561$

3 G. P. Van Wezel and K. J. McDowall, Nat. Prod. Rep., 2011, 28, $1311-1333$

4 (a) A. C. Ross and J. C. Vederas, J. Antibiot, 2011, 64, 27-34; (b) H. Abriouel, C. M. A. P. Franz, O. N. Ben and A. Galvez, FEMS Microbiol. Rev., 2011, 35, 201-232; (c) J. M. Wiley and W. A. van der Donk, Annu. Rev. Microbiol., 2007, 61, 477-501.

5 (a) L. A. Rogers, J. Bacteriol., 1928, 16, 321-325; (b) P. D. Cotter, C. Hill and R. P. Ross, Nat. Rev. Microbiol., 2005, 3, 777-788.

6 (a) H. E. Hasper, N. E. Kramer, J. L. Smith, J. D. Hillman, C. Zachariah, O. P. Kuipers, B. de Kruijff and E. Breuking, Science, 2006, 313, 1636-1637; (b) E. Breukink and B. de Kruijff, Nat. Rev. Drug Discovery, 2006, 5, 321-332.

7 J. M. Wiley and W. A. van der Donk, Annu. Rev. Microbiol., 2007, 61, 477-501.

8 C. Piper, P. D. Cotter, R. P. Ross and C. Hill, Curr. Drug Discovery Technol., 2009, 6, 1-18.

9 T. J. Oman and W. A. van der Donk, Nat. Chem. Biol., 2010, 6, 9-18.

10 K. Meindl, T. Schmiederer, K. Schneider, A. Reicke, D. Butz, S. Keller, H. Gühring, L. Vertesy, J. Wink, H. Hoffmann, M. Brönstrup, G. M. Sheldrick and R. D. Süssmuth, Angew. Chem., Int. Ed., 2010, 49, $1151-1154$.

11 (a) H. E. Meyer, M. Heber, B. Eisermann, H. Korte, J. W. Metzger and G. Jung, Anal. Biochem., 1994, 223, 185-190; (b) N. Zimmermann, J. W. Metzger and G. Jung, Eur. J. Biochem., 1995, 228, 786-797; (c) J. Cortes, A. N. Appleyard and M. J. Dawson, Methods Enzymol., 2009, 458, 559-574; (d) L. Smith, J. Novak, J. Rocca, S. McClung, J. D. Hillman and A. S. Edison, Eur. J. Biochem., 2000, 267, 6810-6816.

12 (a) Y. Oda, T. Nagasu and B. T. Chait, Nat. Biotechnol., 2001, 19, 379 382; (b) A. J. Poot, E. Ruijter, T. Nuijens, E. H. C. Dirksen, A. J. R. Heck, M. Slijper, D. T. S. Rijkers and R. M. J. Liskamp, Proteomics, 2006, 6, 6394-6399.

13 J. E. Moses and A. D. Moorhouse, Chem. Soc. Rev., 2007, 36, $1249-1262$.

14 P. P. Geurink, B. I. Florea, N. Li, M. D. Witte, J. Verasdonck, C. L. Kuo, G. A. van derMarel and H. S. Overkleeft, Angew. Chem., Int. Ed., 2010, 49, 6802-6805.

15 (a) W. W. Niu and H. C. Neu, Antimicrob. Agents Chemother., 1991, 35, 998-1000; (b) S. Chatterjee, D. K. Chatterjee, R. H. Jani, J. Blumbach, B. N. Ganguli, N. Klesel, M. Limbert and G. Seibert, J. Antibiot., 1992, 45, 839-845; (c) G. Bierbaum, H. Brotz, K. P. Koller and H. G. Sahl, FEMS Microbiol. Lett., 1995, 127, 121-126; (d) H. Brotz, G. Bierbaum, A. Markus, E. Molitor and H. G. Sahl, Antimicrob. Agents Chemother, 1995, 39, 714-719.

16 R. Vallinayagam, H. Bertschy, Y. Berger, V. Wenger and R. Neier, Synthesis, 2007, 3731-3735.

17 H. Shi, A. Xu, S. Yao and K. Liu, Chem. Commun., 2009, 5030-5032. 